\title{
ANALISIS DAMPAK BANTUAN LANGSUNG PUMP PERIKANAN TANGKAP DI KABUPATEN SUKABUMI JAWA BARAT TAHUN 2011
}

\author{
Muhamad Karim \\ Dosen Program Studi Agribisnis, Fakultas Bio-industri, Universitas Trilogi \\ Jl.Taman Makam Pahlawan No.1 Kalibata, Jakarta Selatan 12760 \\ Email: commit.nusantao@gmail.com
}

\begin{abstract}
RINGKASAN
Program Pengembangan Usaha Mina Perdesaan (PUMP) yang dilakukan Kementerian Kelautan dan Perikanan (KKP) Tahun 2011 merupakan program peningkatan produktivitas perikanan agar meningkatkan kesejahteraan nelayan. Penelitian ini dilakukan dengan tujuan: (i) mengevaluasi problem kebijakan dan implementasi pedoman Program bantuan langsung PUMP Perikanan Tangkap kepada masyarakat nelayan di Kabupaten Sukabumi, (ii) mengidentifikasi dan menganalisis dampak bantuan langsung PUMP Perikanan Tangkap terhadap peningkatan kesejahteraan nelayan di Kabupaten Sukabumi, dan (iii) memberikan rumusan rekomendasi kebijakan untuk penyempurnaan pelaksanaan bantuan langsung kepada nelayan penangkap ikan di Kabupaten Sukabumi maupun masyarakat perikanan dan kelautan secara umum. Metode analisis yang digunakan dalam penelitian ini adalah Penilaian Dampak Analisis Kebijakan (Regulatory Impact Assesment/RIA). Hasil penelitian menunjukkan bahwa: (1) problem kebijakan dan implementasi pedoman PUMP Perikanan Tangkap kepada masyarakat nelayan di Sukabumi adalah administrasi pencairan bantuan langsung program kurang sesuai dengan kondisi alamiah yang dialami nelayan, (2) dampak bantuan langsung program terhadap nelayan dan buruh nelayan adalah nelayan yang sudah memiliki aset sarana produksi perikanan akan mendapatkan tambahan aset baru. Sementara buruh nelayan mendapatkan aset sarana produksi perikanan yang semula belum memilikinya dan (3) merevisi petunjuk teknis program penyaluran bantuan langsung dengan dibuat lebih sederhana dan fleksibel sehingga dapat menyesuaikan dengan fluktuasi harga faktor produksi di pasaran serta mengatasi problem time-line waktu pencairannya.

Kata kunci: PUMP perikanan tangkap, RIA, petunjuk teknis
\end{abstract}

\section{PERNYATAAN KUNCI}

- Program bantuan langsung PUMP Perikanan Tangkap merupakan kebijakan afirmatif pemerintah khususnya Kementerian Kelautan dan Perikanan (KKP) untuk meningkatkan kesejahteraan nelayan, namun dalam pelaksanaannya menimbulkan problem dan juga keberhasilan. Salah satu problem pokok dari kebijakan dan implementasi pedoman 
Program bantuan langsung PUMP Perikanan Tangkap terhadap nelayan di Kabupaten Sukabumi adalah administrasi pencairan bantuan langsung program tersebut. Hal ini mengakibatkan adanya ketidaksesuaian antara kondisi alamiah yang dialami nelayan dengan proses turunnya bantuan tersebut pada mereka. Ketidaksesuaian tersebut antara lain: waktu musim penangkapan ikan, fishing ground dan daya jelajah mesin kapal.

- Bantun langsung PUMP Perikanan Tangkap terhadap nelayan dan buruh nelayan yang tergabung dalam kelompok usaha bersama (KUB) Fajar Mandiri di Kabupaten Sukabumi telah memberikan dampak bagi nelayan, yaitu yang sudah memiliki aset sarana produksi perikanan mendapatkan tambahan aset baru, sedangkan buruh nelayan mendapatkan aset sarana produksi perikanan yang semula belum dimilikinya.

- Program serupa di masa datang memerlukan penyempurnaan terutama terkait petunjuk teknik program yang harus dibuat lebih serderhana dan lebih fleksibel. Hal ini dimaksudkan agar pada saat program diturunkan ke nelayan mampu menyesuaikan dengan fluktuasi harga faktor produksi yang berlaku di pasar. Selain itu, penyempurnaan ini juga akan dapat mengatasi problem time-line waktu pencairan dana yang berdampak pada ketidaksinkronan antara kondisi alamiah yang dialami nelayan seperti musim ikan, perubahan fishing ground dan masa paceklik dengan kondisi aktual dalam administrasi pencairan dana bantuan langsung.

\section{REKOMENDASI KEBIJAKAN}

- Proses penyaluran bantuan langsung PUMP
Perikanan Tangkap di Kabupaten Sukabumi sebaiknya dilakukan melalui mekanisme penyaluran yang bersifat lebih sederhana sehingga tidak kaku serta tidak melanggar ketentuan administrasi dan birokrasi pemerintahan yang berlaku menurut peraturan perundangan.

- Kondisi empiris dalam pembelian faktor produksi untuk penangkapan ikan (kapal, alat tangkap dan mesin) adalah bahwa anggaran yang diajukan oleh KUB nelayan berbentuk Rencana Anggaran Biaya (RAB) ketika dicairkan harga sarana produksi perikanan yang dibeli mengalami peningkatan. Akibatnya, nelayan dalam KUB Fajar Mandiri melakukan kesepakatan penanggulangan biaya kekurangannya secara "tanggung renteng" sehingga dapat membeli kebutuhan sarana produksi penangkapan ikan sesuai harga pasaran.

- Untuk mengatasi problem time-line dalam pencairan dana yang mengakibatkan tidak sinkronnya antara kondisi alamiah yang dialami nelayan seperti musim ikan, perubahan fishing ground dan masa paceklik, maka mekanisme pencairan dana dibuat lebih fleksibel dan prosesnya satu tahap saja dengan prasyarat tidak bertentangan dengan peraturan perundangan yang berlaku sehingga mencapai sasaran dan tujuan yang diinginkan secara optimal.

\section{PENDAHULUAN}

Program Pengembangan Usaha Mina Perdesaan (PUMP) yang dilaksanakan Kementerian Kelautan dan Perikanan (KKP) di Kabupaten Sukabumi mulai tahun 2011 
merupakan salah satu kegiatan untuk meningkatkan produktivitas sektor kelautan dan perikanan sehingga dapat meningkatkan kesejahteraan nelayan. Secara umum tujuan program PUMP kelautan dan perikanan adalah mendorong peningkatan produksi, nilai tambah, menumbuhkan wirausaha baru; meningkatkan kemampuan, pendapatan dan kesejahteraan masyarakat perikanan secara berkelanjutan; meningkatkan fungsi kelembagaan kelompok yang kuat serta membangun jejaring atau mitra lembaga keuangan untuk mengakses permodalan usaha perikanan (KKP, 2011). Pelaksanaan program ini didasarkan pada beberapa ketentuan hukum, yaitu: (i) Keputusan Menteri Koordinator Bidang Kesejahteraan Rakyat (Menkokesra) Nomor 25 tahun 2007 tentang Pedoman Umum Program Nasional Pemberdayaan Masyarakat Mandiri, (ii) Peraturan Presiden (Perpres) Nomor 15 Tahun 2010 tentang Percepatan Penanggulangan Kemiskinan, (iii) Peraturan Menteri Kelautan dan Perikanan 41 Tahun 2011 tentang Pedoman Pelaksanaan Program Nasional Pemberdayaan Masyarakat Mandiri Kelautan dan Perikanan 2011, (iv) Peraturan Menteri Kelautan dan Perikanan No 2 Tahun 2013 tentang Pedoman Pelaksanaan Program Nasional Pemberdayaan Masyarakat Mandiri Kelautan dan Perikanan dan (v) Keputusan Direktur Jenderal Perikanan Tangkap KKP No 32 Tahun 2014 tentang Pedoman Teknis Pelaksanaan Kegiatan Pengembangan Usaha Mina Perdesaan Bidang Perikanan Tangkap tahun 2014.

Program ini dilakukan melalui penyaluran bantuan kepada kelompok usaha bersama (KUB) yang beranggotakan nelayan. Penyaluran bantuan ini merupakan implementasi misi Kementerian Kelautan dan Perikanan untuk mencapai terwujudnya kesejahteraan bagi masyarakat kelautan dan perikanan di Indonesia.

Program PUMP kelautan dan perikanan merupakan bagian dari pelaksanaan Program Nasional Pemberdayaan Masyarakat (PNPM) Mandiri yang dilakukan Kementerian Kelautan dan Perikanan (KKP). Peraturan Menteri Kelautan dan Perikanan No. 10 Tahun 2014 tentang Pedoman Pelaksanaan Program Nasional Pemberdayaan Masyarakat Mandiri Kelautan dan Perikanan menyebutkan bahwa tujuan dari program ini adalah untuk meningkatkan kemampuan usaha dan kesejahteraan, pengembangan wirausaha anggota KUKP dan meningkatnya kualitas lingkungan (KKP, 2014). Salah satu implementasi program PUMP adalah melalui bantuan modal usaha bidang perikanan tangkap yang disebut PUMP Perikanan Tangkap. Mekanisme penyaluran PUMP perikanan tangkap disesuaikan dengan potensi sumber daya perikanan di daerah sasaran.

Dalam pedoman pelaksanaan PUMP dicantumkan bahwa sasaran utama program ini adalah terbentuknya KUB. KUB tersebut secara kelembagaan merupakan badan usaha non badan hukum maupun yang telah berbadan hukum berbentuk kelompok yang dibentuk nelayan. Pembentukan kelembagaan KUB tersebut dilakukan berdasarkan hasil kesepakatan musyawarah-mufakat oleh seluruh anggota nelayan yang dilandasi keinginan bersama untuk berusaha bersama dan dapat dipertanggungjawabkan secara kolektif sehingga meningkatkan pendapatan anggotanya. Dalam membentuk KUB, sebaiknya dibangun melalui kerangka pranata-pranata dan jaringan sosial yang dimiliki masyarakat nelayan di suatu lokasi. Eksistensi pranata-pranata dan jaringan sosial tersebut memiliki makna yang berarti dan bernilai strategis bagi rumah tangga nelayan (Kusnadi, 2003). 
Kelompok ini nantinya menjadi wadah atau tempat bagi anggotanya untuk mengembangkan tujuan yang hendak dicapai dengan adanya program PUMP.

Secara obyektif, KUB pada masyarakat nelayan sebetulnya telah terbentuk sejak adanya bantuan PNPM Kelautan dan Perikanan. KUB yang mendapatkan Program PUMP merupakan keberlanjutan dari Kelompok Usaha Mandiri (KUM) yang sebelumnya melaksanakan PNPM Mandiri. Dengan terbentuknya KUB di tingkat kelurahan dalam suatu kabupaten, akan menjadi suatu langkah baru bagi masyarakat nelayan untuk meningkatkan kesejahteraan hidupnya secara mandiri.

Kabupaten Sukabumi merupakan salah satu wilayah yang mendapatkan program PUMP Perikanan tangkap sejak tahun 2011. Kondisi masyarakat nelayan di daerah ini perlu mendapatkan perhatian serius karena sebagian besar nelayannya menggantungkan hidupnya dari sumber daya kelautan khususnya perikanan tangkap. Nelayan di daerah ini seringkali menghadapi permasalahan-permasalah yang mengakibatkan tingkat kehidupan sosial ekonominya tidak mengalami perkembangan berarti. Permasalahan tersebut antara lain: (i) rendahnya pendapatan dari hasil laut yang diperoleh akibat keterbatasan biaya operasional penangkapan ikan, (ii) kemiskinan struktural yang dialami serta ketersediaan sarana penangkapan ikan yang kurang memadai yaitu menggunakan alat tangkap pancing yang masih bersifat tradisional; (iii) perahu tangkap yang digunakan belum dilengkapi fasilitas pendukunng dalam proses penangkapan ikan untuk memudahkan dalam mendeteksi lokasi fishing ground ikan.

Dikembangkannya penyaluran bantuan program PUMP perikanan tangkap di daerah ini sangat bermanfaat bagi nelayan di Kabupaten Sukabumi karena mereka dapat meningkatkan kegiatan penangkapan ikan di wilayah perairan lautnya. Nelayan mendapatkan manfaat yaitu dapat menambah atau mengganti aset sarana penangkapan ikan yang mereka miliki.

Program bantuan langsung PUMP Perikanan Tangkap yang berlangsung pada tahun 2011 tersebut perlu dievaluasi. Evaluasi tersebut dilakukan untuk mengetahui bagaimana dampaknya terhadap peningkatan kesejahteraan nelayan yang menjadi sasaran program, khususnya nelayan di Kabupaten Sukabumi. Hasil evaluasi ini diharapkan dapat memberikan sumbangan pemikiran agar program-program yang serupa pada masa datang dapat berjalan secara efektif dan mengalami perbaikan-perbaikan sehingga nelayan mendapatkan manfaat yang signifikan untuk meningkatkan kesejahteraannya.

Tujuan penelitian ini adalah:

Mengevaluasi problem kebijakan dan implementasi pedoman Program bantuan langsung PUMP Perikanan Tangkap kepada masyarakat nelayan di Kabupaten Sukabumi, (ii) Mengidentifikasi dan menganalisis dampak bantuan langsung PUMP Perikanan Tangkap terhadap peningkatan kesejahteraan nelayan di Kabupaten Sukabumi dan (iii) Memberikan rumusan rekomendasi kebijakan untuk penyempurnaan pelaksanaan bantuan langsung kepada nelayan penangkap ikan di Kabupaten Sukabumi maupun masyarakat perikanan dan kelautan secara umum.

\section{SITUASI TERKINI}

Penyaluran bantuan langsung PUMP Perikanan Tangkap Tahun 2011 di Kabupaten 
Sukabumi dilaksanakan melalui KUB. Salah satu KUB yang mendapatkan bantuan tersebut adalah KUB Fajar Mandiri yang beranggotakan nelayan. Nelayan yang bergabung dalam KUB Fajar Mandiri sebelum mendapatkan bantuan PUMP Perikanan Tangkap menggunakan kapal kayu. KUB Fajar Mandiri ini dikukuhkan melalui Akte Notaris No: $800 / 149.7 /$ TANGKAP, 01/03/2011. Setelah kelembagaan KUB ini dikukuhkan pada tahun 2011, selanjutnya mendapatkan bantuan kapal ikan dari Kementerian Kelautan dan Perikanan melalui skema Program PUMP perikanan tangkap tahun 2011, sehingga nelayan yang tergabung dalam KUB tersebut kemudian menggunakan kapal fiber.

Secara makro, bantuan PUMP Perikanan Tangkap telah memberikan perbaikan terhadap tingkat kesejahteraan nelayan. Untuk melihat perbaikan tingkat kesejahteraan nelayan pada saat ini digunakan nilai tukar nelayan (NTN). NTN yang digunakan di sini adalah nilai tukar nelayan (NTN) Jawa Barat. Penggunaan NTN Jawa Barat ini disebabkan karena basis data perhitungan
NTN baru pada level provinsi dan belum ada di level Kabupaten/Kota di Indonesia. Data NTN menunjukkan bahwa dari tahun 2011-2013 NTN di Jawa Barat mengalami peningkatan, sedangkan tahun 2014 menurun kemudian meningkat lagi pada tahun 2015.

Secara mikro, dampak dari bantuan PUMP Perikanan Tangkap tahun 2011 di Kabupaten Sukabumi terlihat dari keberhasilan nelayan yang tergabung dalam KUB Fajar Mandiri yang telah mendapatkan bantuan tersebut. Bentuk kesuksesan tersebut menurut Sunardi (2016) adalah:

Pertama, pada awal menerima bantuan tahun 2011, KUB Fajar Mandiri hanya memiliki tiga unit kapal dengan ukuran <5 GT dengan jumlah anggota 10 orang. KUD Fajar Mandiri kemudian mengelola pengoperasian bantuan kapal tersebut secara kelompok. Dengan menggunakan mekanisme perputaran modal awal dan tanggung renteng di antara anggota KUB, selama periode 2011-2016 jumlah kapal nelayan bertambah sebanyak 25 unit. Mekanisme pertambahan tersebut karena anggota KUD Fajar Mandiri selain

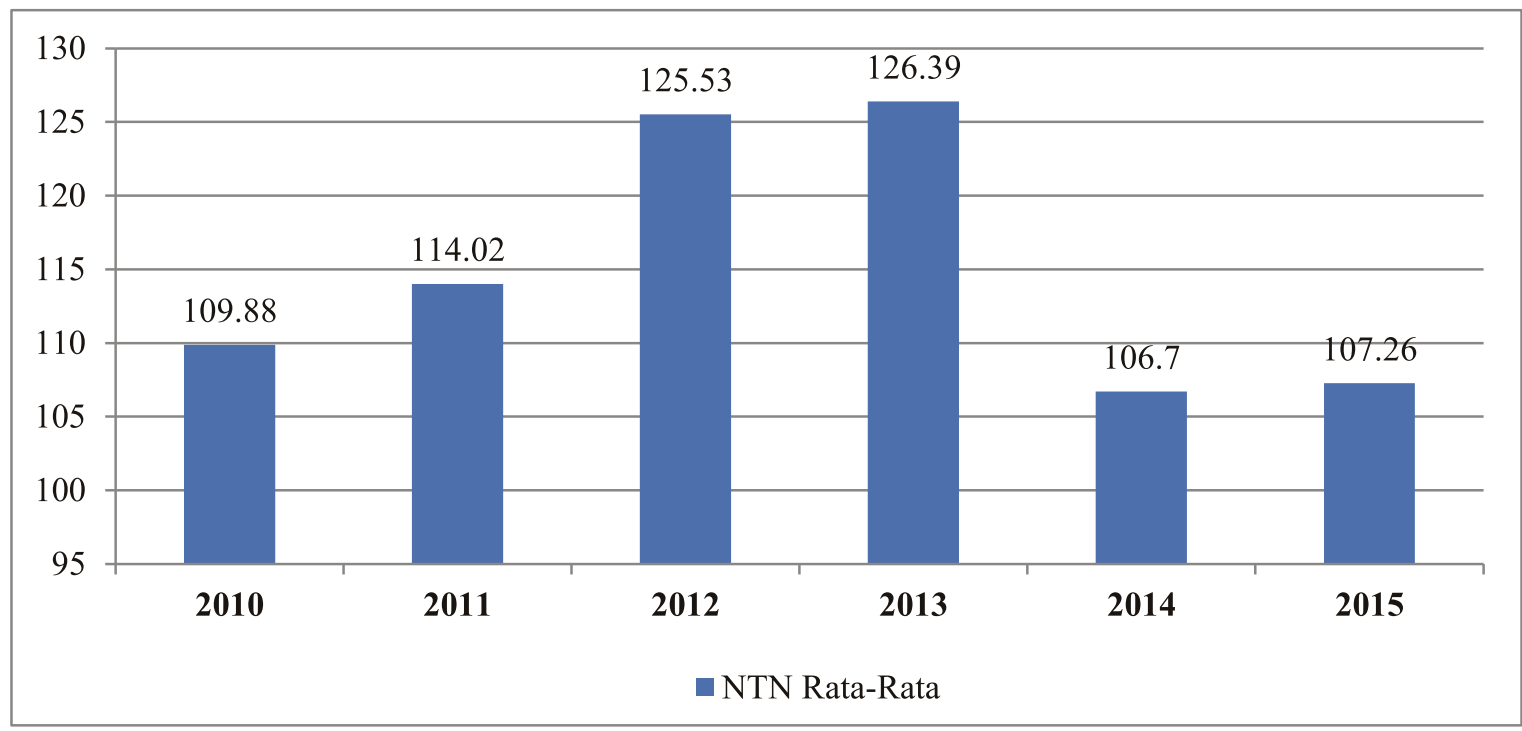

Gambar 2. Nilai tukar nelayan Jawa Barat 2010-2015

(Sumber: BPS Jawa Barat 2015 dan 2016) 


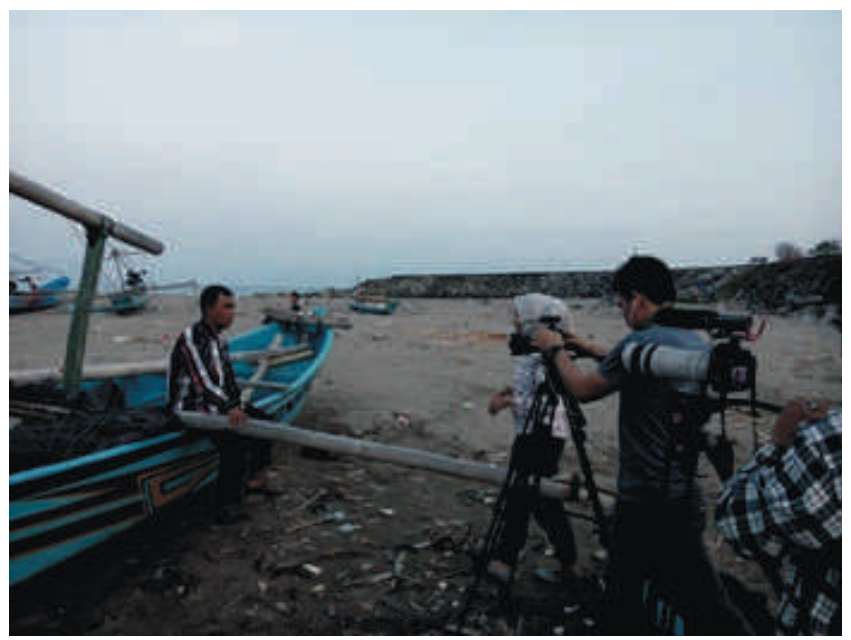

Gambar 3. Kapal bantun PUMP perikanan tangkap KUB/Koperasi Fajar Mandiri (Sumber: Diadopsi dari Sunardi, 2016)

melakukan simpanan wajib dan simpanan pokok juga melakukan tabungan untuk mendapatkan kapal baru bagi anggota KUB yang belum memiliki kapal. Proses ini terus berlangsung sehingga tahun 2016 nelayan anggota KUB telah memiliki 25 unit kapal.

Kedua, akibat bertambahnya jumlah anggota KUB Fajar Mandiri menjadi 45 orang, maka KUB Fajar Mandiri melakukan transformasi status kelembagaannya dari KUB menjadi Koperasi Fajar Mandiri. Perubahan kelembagaan ini merupakan langkah strategis karena jumlah anggota KUB telah mencapai 45 orang dan lingkup unit usahanya bertambah. Perkembangan lingkup unit usaha yang dilakukan KUB Fajar Mandiri yaitu pemasaran, simpan pinjam dan kios sarana produksi.

Ketiga, secara obyektif keuangan di KUD Fajar Mandiri tahun 2011 mencapai Rp 179.000.000 yang merupakan simpanan anggota dan $\mathrm{Rp}$ 100.000.000 bersumber dari bantuan langsung PUMP Perikanan Tangkap Tahun 2011. Pada awalnya aset milik KUB berjumlah Rp 314.000.000 yang terdiri dari: (i) aset langsung usaha (perahu, mesin tempel $15 \mathrm{PK}$, alat tangkap, mesin gantar, 5,5 PK) yang berjumlah $\mathrm{Rp}$ 262.000.000 dan (ii) aset fasilitas usaha (cool box dan fasilitas penunjang) sebesar Rp 52.000.000.

Keempat, komoditas ikan yang diusahakan KUB Fajar Mandiri adalah ikan tongkol, ikan campuran, dan ikan tenggiri. Komoditas unggulan perikanan yang diusahakan KUB Fajar Mandiri hingga kini yang telah berubah menjadi Koperasi Fajar Mandiri adalah ikan layur.

Kelima, KUB Fajar Mandiri dalam perkembangannnya sejak tahun 2011 - 2016 telah mendapatkan pelatihan dan bimbingan teknis antara lain: (i) sosialisasi kartu nelayan tahun 2012, (ii) sosialisasi PUMP Kelautan Perikanan 2012, dan (iii) bimbingan teknis pengembangan usaha perikanan tangkap bagi PUMP perikanan tangkap tahun 2014

Berdasarkan uraian di atas, KUB Fajar Mandiri dalam perjalanannya telah mengalami penambahan jumlah aset dan anggota KUB dan kelembagaanya berubah menjadi Koperasi Fajar Mandiri. Hal ini menunjukkan bahwa telah terjadi perbaikan tingkat kesejahteraan nelayan yang menjadi anggotanya karena bertambahnya aset sehingga mempengaruhi peningkatan hasil 
tangkapan yang berpengaruh pada pendapatan nelayan. Akibatnya, sewaktu masih bersatus KUB Fajar Mandiri telah mendapatkan penghargaan yaitu KUB Mandiri terbaik se-Kabupaten Sukabumi tahun 2012.

\section{METODOLOGI}

Penelitian ini dilakukan di Kabupaten Sukabumi Jawa Barat pada bulan September tahun 2016. Penentuan lokasi daerah ini sebagai kasus untuk mengevaluasi bantuan langsung kepada nelayan didasarkan pada pertimbangan bahwa daerah ini merupakan salah satu basis perikanan tangkap di wilayah Jawa Barat yang langsung berhadapan dengan Samudera Hindia dan mendapatkan bantuan langsung dari Kementerian Kelautan dan Perikanan tahun 2011. Artinya, dalam kurun waktu lima tahun dampak bantuan tersebut sudah bisa dilihat hasilnya.

Sebelum pelaksanaan penelitian lapangan telah dilakukan kegiatan-kegiatan persiapan awal yang meliputi pengumpulan data dan informasi sekunder, verifikasi dan analisis data sekunder, serta menentukan pendekatan dan metode yang digunakan dalam penelitian ini. Data sekunder yang telah dikumpulkan antara lain: dokumen pedoman PUMP Perikanan Tangkap dari KKP tahun 2011 dan rata-rata nilai tukar nelayan (NTN) Provinsi Jawa Barat Tahun 2010-2015. Data-data sekunder tersebut diperoleh dari BPS Kabupaten Sukabumi, Kementerian Kelautan dan Perikanan (KKP) dan berbagai situs web di internet.

Data primer dalam penelitian ini diperoleh melalui metode Focus Group Discussion (FGD). FGD dilaksanakan dengan jumlah peserta 7-10 orang yang dilakukan secara partisipatif dengan teknik diskusi terfokus. Semua peserta FGD merupakan sumber informasi utama. Peserta yang hadir dalam FGD ini adalah: (i) Kelompok penerima bantuan PUMP bidang perikanan tangkap Tahun 2011 yang berasal dari Kelompok Fajar Mandiri yang sekarang berubah menjadi Koperasi Fajar Mandiri Kp. Pajagan RT 01 RW 09 Desa Cikahuripan Kecamatan Cisolok Kabupaten Sukabumi, (ii) Kementerian Kelautan dan Perikanan, (iii) Dinas Kelautan dan Perikanan Kabupaten Sukabumi dan (iv) Fasilitator dari Tim ahli yang melaksanakan kegiatan ini. Pelaksanaan pertama FGD dilakukan pada kelompok penerima bantuan perikanan tangkap yang hasilnya tersaji dalam hasil analisis RIA dalam penelitian ini.

Dalam proses FGD ini semua peserta FGD aktif memberikan masukan maupun koreksi yang difasilitasi oleh Fasilitator. Fungsi fasilitator yakni mengarahkan, memandu dan mengatur jalannya diskusi serta meluruskan substansi bila sudah melenceng dari pokok masalah yang dibahas. Fasilitator dibantu Notulen yang mencatat sekaligus membuat rumusan awal hasil pelaksanaan FGD. Secara teknis, Notulen langsung merekam/menuliskan semua hasil masukan, saran, isu/masalah dan solusi alternatif pada komputer/laptop (Irwanto, 2006).

Dalam pelaksanaan FGD ini peralatan/bahan yang digunakan yaitu: (i) Kertas Plano, (ii) Papan tulis (Whiteboard), (iii) Peralatan tulis menulis (Spidol besar dan kecil, pulpen), (v) Camera digital dan (vii) Alat perekam. Sejumlah peralatan tersebut dianggap penting, agar hal-hal yang tidak tercatat oleh notulis dapat terekam dengan baik untuk menyempurnakan hasil penelitian. Hasil yang diperoleh dari FGD ini merupakan bahan yang digunakan dalam analisis hasil evaluasi program bantuan langsung PUMP Perikanan Tangkap dengan menggunakan metode 
pendekatan RIA.

Metode analisis data yang digunakan dalam penelitian ini adalah metode Penilaian Dampak Analisis Kebijakan (Regulatory Impact Assesment/RIA) (Wardani et al., 2008). Kebijakan yang dimaksudkan dalam penelitian ini adalah kebijakan PUMP Perikanan Tangkap yang telah berlangsung pada tahun 2011 di Kabupaten Sukabumi. Metode ini secara empiris merupakan metode riset partisipatoris yang melibatkan berbagai pihak dalam pelaksanaan program ini.

Penerapan metode RIA dalam menilai kebijakan ternyata dilakukan bukan hanya dalam bidang ekonomi, melainkan dalam bidang sosial dan lingkungan. Hal ini dapat ditemukan dari hasil studi Kirkpatrick dan Yin-Fang (2004) dan disajikan dalam Tabel 1 .

Dari Tabel ini menunjukkan bahwa banyak negara-negara berkembang di dunia ini yang menerapkan metode RIA dalam menilai kebijakan sosial dan lingkungan selain ekonomi. Hal ini mengandung pengertian bahwa penerapan RIA tidak hanya dalam bidang ekonomi.

Wardani et al., (2008) menyatakan bahwa tahapan-tahapan yang dilakukan dalam analisis RIA ini adalah: Pertama, melakukan identifikasi dan analisis masalah terkait kebijakan PUMP Perikanan Tangkap di Kabupaten Sukabumi. Langkah ini dilakukan agar semua pihak yang utamanya terlibat dalam proses pengambilan kebijakan dapat melihat dan memetakan dengan jelas masalah apa sebenarnya yang dihadapi dan harus diselesaikan terkait kebijakan tersebut. Pada tahapan yang paling penting adalah membedakan antara masalah (problem) dengan gejala (symptom). Oleh karena yang ingin dipecahkan adalah masalah bukan gejalanya.

Kedua, penetapan tujuan. Setelah masalah diidentifikasi, langkah selanjutnya adalah perlu menetapkan apa tujuan sebenarnya dari kebijakan yang hendak diambil. Penetapan tujuan ini dalam metode RIA menjadi salah satu komponen yang sangat penting karena terkait keefektifan sebuah kebijakan. Apabila akan dilakukan suatu penilaian terhadap keefektifan kebijakan, maka yang dimaksud dengan "keefektifan" adalah terkait pencapaian tujuan sebuah kebijakan, apakah tercapai atau tidak.

Ketiga, pengembangan berbagai pilihan/ alternatif kebijakan untuk mencapai tujuan. Setelah masalah yang ingin dipecahkan dan tujuan kebijakan sudah jelas, maka langkah selanjutnya adalah menilai dan menentukan pilihan kebijakan apa saja yang tersedia atau dapat diambil untuk memecahkan masalah tersebut. Dalam metode RIA, pilihan atau alternatif kebijakan pertama adalah "do nothing" atau tidak melakukan apa-apa, yang pada tahap berikutnya akan dianggap sebagai kondisi awal (baseline) untuk dibandingkan dengan berbagai opsi/pilihan kebijakan yang ada. Pada

Tabel 1. Jumlah negara sedang berkembang yang menerapkan metode RIA untuk berbagai kebijakan

\begin{tabular}{|c|c|c|c|}
\hline \multirow{2}{*}{ Kawasan } & \multicolumn{3}{|c|}{ Kebijakan } \\
\hline & Ekonomi & Sosial & Lingkungan \\
\hline Asia & 8 & 8 & 5 \\
\hline Afrika & 10 & 5 & 7 \\
\hline Amerika Latin & 5 & 3 & 5 \\
\hline Negara sedang berkembang lain & 5 & 5 & 4 \\
\hline
\end{tabular}

Sumber: Kirkpatrick dan Yin-Fang (2004) 
tahapan ini yang penting adalah melibatkan pemangku kepentingan (stakeholders) dari berbagai latar belakang dan kepentingan guna mendapatkan gambaran seluas-luasnya tentang opsi/pilihan kebijakan apa saja yang tersedia.

Keempat, penilaian terhadap pilihan alternatif kebijakan baik dari sisi legalitas maupun biaya (cost) dan manfaat (benefit). Setelah berbagai opsi/pilihan kebijakan untuk memecahkan masalah yang telah teridentifikasi, maka langkah berikutnya adalah menyeleksi berbagai pilihan kebijakan. Proses seleksi kebijakan diawali dengan penilaian dari aspek legalitas. Hal ini dilakukan karena setiap opsi/pilihan kebijakan tidak boleh bertentangan dengan peraturan perundangan yang berlaku. Pilihan-pilihan kebijakan yang tidak bertentangan dengan peraturan perundangan yang berlaku, kemudian dianalisis terhadap biaya (cost) dan manfaat (benefit) pada setiap pilihan tersebut. Secara sederhana, "biaya" adalah hal-hal negatif atau merugikan suatu pihak jika pilihan tersebut diambil, sementara, "manfaat" adalah hal-hal positif atau menguntungkan suatu pihak. Biaya atau manfaat dalam hal ini tidak selalu diartikan "uang". Oleh karena itu, dalam konteks identifikasi biaya dan manfaat sebuah kebijakan, perlu dilakukan identifikasi tentang siapa saja yang terkena dampak dan siapa saja yang mendapatkan manfaat akibat adanya suatu pilihan kebijakan (termasuk kalau kebijakan yang diambil adalah tidak melakukan apa-apa atau do notbing).

Kelima, pemilihan kebijakan terbaik. Analisis biaya-manfaat kemudian menjadi dasar untuk mengambil keputusan tentang opsi/pilihan kebijakan yang akan diambil. Opsi/pilihan kebijakan yang diambil adalah kebijakan yang memiliki manfaat bersih (net benefit), yaitu jumlah semua manfaat dikurangi dengan jumlah semua biaya terbesar. Pemillihan kebijakan terbaik dapat dilakukan secara kuantitatif dengan mekanisme skoring sebagaimana disajikan dalam Tabel 2 .

Keenam, penyusunan strategi implementasi. Langkah ini diambil berdasarkan kesadaran bahwa sebuah kebijakan tidak bisa berjalan secara otomatis setelah ditetapkan atau diambil. Dengan demikian, pemerintah dan pihak lain yang terkait tidak hanya mengetahui apa yang akan dilakukan, tetapi juga bagaimana melakukannya.

Tabel 2. Screening alternatif tindakan dengan mekanisme skoring

\begin{tabular}{|c|c|c|}
\hline Faktor & Skor & Keterangan \\
\hline \multirow{3}{*}{ Legalitas } & 0 & Tidak melanggar ketentuan legal \\
\hline & -2 & Kemungkinan melanggar ketentuan legal \\
\hline & -4 & Melanggar ketentuan legal \\
\hline \multirow{4}{*}{ Biaya } & 0 & Tidak ada biaya atau biayanya tidak berarti \\
\hline & -1 & Biayanya kecil \\
\hline & -2 & Biayanya sedang \\
\hline & -3 & Biayanya besar \\
\hline \multirow{4}{*}{ Dampak } & -2 & Sangat negatif \\
\hline & -1 & Negatif sedang \\
\hline & 1 & Positif sedang \\
\hline & 2 & Sangat positif \\
\hline \multirow{4}{*}{ Kemungkinan mencapai tujuan } & 1 & Sangat kecil \\
\hline & 2 & Sedang \\
\hline & 3 & Besar \\
\hline & 4 & Sangat besar \\
\hline
\end{tabular}

Sumber: Wardani et al., 2008 


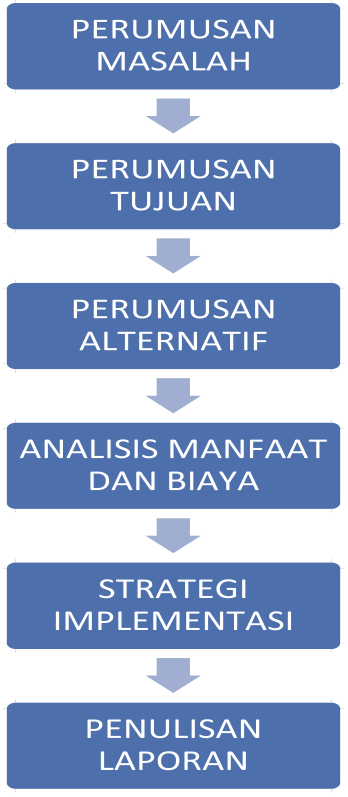

Gambar 1 Tahapan-tahapan RIA

Ketujuh, partisipasi masyarakat di semua proses. Semua tahapan dalam analisis RIA ini melibatkan berbagai pemangku kepentingan yang terlibat secara langsung maupun tidak langsung terkait kebijakan yang disusun. Masyarakat nelayan sebagai pemangku kepentingan mutlak harus didengar suaranya karena mereka yang menerima dampak kebijakan (key stakeholder).

\section{ANALISIS DAN ALTERNATIF SOLUSI/PENANGANAN}

\section{Permasalahan dan Tujuan}

Dengan menggunakan pendekatan analisis RIA, hasil rumusan identifikasi permasalahan dan tujuan dalam penelitian ini disajikan dalam tabeltabel di bawah ini.

Tabel 3 menunjukkan bahwa pelaku yang terlibat dalam penyaluran bantuan langsung PUMP Perikanan Tangkap di Kabupaten Sukabumi adalah KUB Fajar Mandiri, Dinas Perikanan dan Kelautan Kabupaten Sukabumi, Pemerintahan Desa dan Kementerian Kelautan dan Perikanan. Peran yang dilakukan dari para pelaku yang terlibat tersebut dapat dijelaskan dari perilaku masing-masing pemangku kepentingan sebagaimana dijelaskan dalam Tabel 3 .

Pada Tabel 4 terlihat bahwa masalah utama yang dihadapi dari penyaluran bantuan PUMP Perikanan Tangkap di Kabupaten Sukabumi adalah keterlambatan turunnya dana bantuan langsung akibat proses administrasi dalam mencairkan dana sehingga kurang sesuai dengan waktu musim ikan, fishing ground dan daya jelajah mesin kapal. Hal ini menyebabkan nelayan tidak bisa memanfaatkannya, padahal anggaran tidak bisa dibelikan sarana produksi perikanan tangkap jika berbeda dengan alokasi yang dianggarkan.

Keterlambatan proses administrasi di daerah ini juga disebabkan keharusan adanya rekomendasi pencairan dari pimpinan instansi terkait (Dinas Kelautan dan Perikanan Kabupaten Sukabumi dan Kepala Desa yang menjadi lokasi KUB Fajar Mandiri) yang tidak bisa diwakilkan. Hal ini terkait dengan beberapa ketentuan peraturan perundangan yang berlaku yang harus dijalankan oleh pemerintah antara lain:

a) Keputusan Menteri Koordinator Bidang Kesejahteraan Rakyat Nomor 25 Tahun 2007 tentang Pedoman Umum Program Nasional Pemberdayaan Masyarakat Mandiri

b) Peraturan Presiden Nomor 15 Tahun 2010 tentang Percepatan Penanggulangan Kemiskinan

c) Peraturan Menteri Kelautan dan Perikanan No 41 Tahun 2011 tentang Pedoman Pelaksanaan Program Nasional Pemberdayaan Masyarakat Mandiri Kelautan dan Perikanan Tahun 2011

d) Peraturan Menteri Kelautan dan Perikanan No 2 Tahun 2013 tentang Pedoman Pelaksanaan Program Nasional Pemberdayaan Masyarakat Mandiri Kelautan dan Perikanan 
Tabel 3. Pelaku dan peranannya

\begin{tabular}{ll}
\hline \multicolumn{1}{c}{ Pelaku } & \multicolumn{1}{c}{ Peranan } \\
\hline KUB Fajar Mandiri Kabupaten Sukabumi & Tahun 2011: Administrasi dan proses pencairan Bantuan \\
(sekarang berubah menjadi Koperasi Fajar & PUMP Perikanan Tangkap mengandung ketidaksesuaian \\
Mandiri) & dengan musim penangkapan ikan, perubahan fishing ground \\
& ikan, dan daya jelajah mesin kapal ikan sehingga mesin dan \\
& alat tangkap yang telah dialokasikan/dibelanjakan dari dana \\
& bantuan dalam proses pengajuan menimbulkan \\
& ketidaksesuain dengan musim dan fishing ground ikan yang \\
& pada saat pengajuan disesuaikan dengan prediksi jenis ikan \\
& yang sedang mengalami musim penangkapan \\
\hline Dinas Perikanan dan Kelautan Kabupaten & Memberikan rekomendasi untuk proses pencairan bantuan \\
& PUMP sesuai dengan ketentuan Petunjuk Teknis (JUKNIS) \\
& yang tidak bisa diwakilkan \\
\hline Pemerintahan Desa & Memberikan rekomendasi untuk proses pencairan bantuan \\
& PUMP yang tidak bisa diwakilkan sesuai JUKNIS \\
\hline Kementerian Kelautan dan Perikanan & Memberikan bantuan program PUMP senilai Rp 100 juta \\
& untuk nelayan penangkap ikan di Kabupaten Sukabumi. \\
& Implementasi proses bantuan didukung oleh JUKNIS yang \\
& dibuat KKP yang administrasi masih agak rumit \\
\hline
\end{tabular}

Sumber: Data Primer Hasil FGD (2016)

Tabel 4. Masalah yang dihadapi dan penyebab timbulnya masalah

\begin{tabular}{ll}
\hline \multicolumn{1}{c}{ Masalah Yang Dihadapi } & \multicolumn{1}{c}{ Penyebab Timbulnya Masalah } \\
\hline Administrasi pencairan bantuan kurang & Dalam proses pencairan dana bantuan langsung PUMP \\
sesuai dengan waktu musim ikan, fishing & Perikanan Tangkap, proses administrasi rekening bantuan \\
ground dan daya jelajah mesin kapal & harus mendapatkan (1) rekomendasi kepada Dinas KKP \\
& Kabupaten dan (2) Rekomendasi kepala Desa setempat \\
\cline { 2 - 2 } & Proses pencairan yang membutuhkan rekomendasi Kepala \\
& Dinas KKP dan kepala desa tersebut tidak bisa diwakilkan \\
& sehingga menjadi kendala ketika kepala Dinas KKP dan \\
& Kepala Desa tidak berada di tempat. Padahal nelayan anggota \\
& kelompok KUB Fajar Mandiri sudah membutuhkan dana \\
& untuk pembelian kapal dan alat tangkapnya \\
\hline & Pencairan dana bantuan PUMP Perikanan Tangkap yang \\
& dilakukan secara bertahap menyebabkan nelayan anggota \\
& kelompok tidak semuanya langsung mendapatkan bantuan \\
& tetapi harus menunggu tahap kedua. Hal ini sesuai dengan \\
& ketentuan Petunjuk Teknis \\
\hline
\end{tabular}

Sumber: Data Primer Hasil FGD (2016)

e) Keputusan Direktur Jenderal Perikanan Tangkap KKP No 32 Tahun 2014 tentang Pedoman Teknis Pelaksanaan Kegiatan Pengembangan Usaha Mina Pedesaan Bidang Perikanan Tangkap tahun 2014.

Tabel 5 menunjukkan bahwa timbulnya masalah yang bersumber dari para pemangku kepentingan yang terlibat dalam penyelenggaraan program ini disebabkan mereka menjalankannya sesuai dengan peraturan perundangan yang telah diatur dalam Pedoman Pelaksanaan Program Nasional Pemberdayaan Masyarakat Mandiri Kelautan dan Perikanan Tahun 2011, Peraturan Menteri Kelautan dan Perikanan No 2 Tahun 2013 tentang Pedoman Pelaksanaan Program Nasional Pemberdayaan Masyarakat Mandiri Kelautan dan Perikanan Tahun dan Keputusan Direktur Jenderal Perikanan Tangkap No 32 Tahun 2014 
Tabel 5. Pihak terkait, perilaku yang menyumbang masalah dan alasan/motivasinya

\begin{tabular}{|c|c|c|}
\hline Siapa Pihak yang Terkait & $\begin{array}{l}\text { Perilaku yang menyumbang } \\
\text { Masalah }\end{array}$ & Alasan/Motivasinya \\
\hline $\begin{array}{l}\text { Nelayan yang tergabung } \\
\text { KUB Falam } \\
\text { berjumlah } 10 \text { orang }\end{array}$ & $\begin{array}{l}\text { Akibat proses administrasi yang } \\
\text { waktunya tidak sesuai dengan } \\
\text { kondisi musim penangkapan, } \\
\text { daerah tangkapan dan alat yang } \\
\text { dibeli menyebabkan } \\
\text { pemanfaatannya kurang optimal }\end{array}$ & $\begin{array}{l}\text { Proses administrasi penyaluran } \\
\text { bantuan time line-nya tidak } \\
\text { diketahui sehingga tidak sesuai } \\
\text { dengan harapan nelayan } \\
\text { khususnya dengan musim ikan, } \\
\text { fishing ground ikan dan daya jelajah } \\
\text { kapal. Hal ini disebabkan daya } \\
\text { jelajah mesin dan alat tangkap } \\
\text { sudah tidak sesuai lagi dengan } \\
\text { perubahan musim ikan }\end{array}$ \\
\hline $\begin{array}{l}\text { Dinas Kelautan dan Perikanan } \\
\text { Kabupaten Sukabumi }\end{array}$ & $\begin{array}{l}\text { Pejabat Dinas KKP Kabupaten } \\
\text { Sukabumi memberikan } \\
\text { rekomendasi sesuai dengan } \\
\text { ketentuan Petunjuk Teknis yang } \\
\text { telah diberikan }\end{array}$ & $\begin{array}{l}\text { Menjalankan fungsi administrasi } \\
\text { sesuai dengan ketentuan Petunjuk } \\
\text { Teknis }\end{array}$ \\
\hline Pemerintahan Desa & $\begin{array}{l}\text { Kepala Desa hanya memberikan } \\
\text { rekomendasi sesuai dengan } \\
\text { ketentuan Petunjuk Teknis yang } \\
\text { telah diberikan }\end{array}$ & $\begin{array}{l}\text { Menjalankan fungsi administrasi } \\
\text { sesuai dengan ketentuan Petunjuk } \\
\text { teknis }\end{array}$ \\
\hline $\begin{array}{lll}\text { Kementerian } & \text { Kelautan } & \text { dan } \\
\text { Perikanan } & & \end{array}$ & $\begin{array}{l}\text { Petunjuk teknis yang dibuat } \\
\text { seringkali dalam proses } \\
\text { implementasi tidak ideal karena } \\
\text { perbedan kondisi alam (musim } \\
\text { tangkap), dan faktor sosial budaya } \\
\text { masyarakat setempat }\end{array}$ & $\begin{array}{l}\text { Menjalankan fungs-fungsi } \\
\text { penganggaran sesuai ketentuan } \\
\text { peraturan tentang penggunaan } \\
\text { keuangan negara yang harus tertib } \\
\text { administrasi sehingga mencegah } \\
\text { terjadinya penyalagunaan }\end{array}$ \\
\hline
\end{tabular}

Sumber: Data Primer Hasil FGD (2016)

tentang Pedoman Teknis Pelaksanaan Kegiatan

Pengembangan Usaha Mina Pedesaan Bidang Perikanan Tangkap tahun 2014. Oleh karenanya, peraturan perundangan yang dibuat mestinya mengatur juga ketentuan yang bisa bersifat fleksibel sehingga tidak menimbulkan masalah baru dalam proses implementasinya.

Tahapan berikutnya dalam pendekatan analisis RIA ini dengan menggunakan metode FGD adalah perumusan tujuan.

\section{Perumusan Tujuan}

Dalam perumusan tujuan dengan pendekatan RIA ini dilakukan beberapa proses sebagaimana disajikan dalam tabel-tabel berikutini.

Tabel 6 menunjukkan bahwa masalah keterlambatan administrasi dalam pencairan bantuan karena adanya faktor pembatas, yaitu regulasi yang dibuat pemerintah pusat khususnya Kementerian Kelautan dan Perikanan. Hal ini tidak salah karena terkait dengan tatakelola keuangan negara yang bersih dan dapat dipertanggungjawabkan. Sesungguhnya adanya regulasi yang dibuat pemerintah dimaksudkan agar bantuan langsung tersebut tidak mengalami keterlambatan dan dapat dimanfaatkan oleh nelayan penerimanya. Namun, problem administrasi yang terlalu "kaku" mengakibatkan keterlambatan akibat proses administrasinya yang harus dipenuhi.

Masalah yang muncul dalam proses administrasi pencairan bantuan langsung PUMP Perikanan Tangkap membutuhkan kebijakan yang bisa memberikan solusi untuk mengatasinya. Hasil FGD memberikan dua kebijakan yaitu: pertama, 
Tabel 6. Masalah, alasan perlunya regulasi dan kondisi yang terjadi jika tidak dibuat regulasi

\begin{tabular}{lll}
\hline \multicolumn{1}{c}{ Masalah } & \multicolumn{1}{c}{ Alasan Perlunya Regulasi } & \multicolumn{1}{c}{$\begin{array}{c}\text { Kondisi yang Terjadi jika tidak } \\
\text { dibuat regulasi }\end{array}$} \\
\hline Administrasi pencairan & $\begin{array}{l}\text { Penyaluran bantuan agar sesuai } \\
\text { dengan waktu musim ikan, fishing }\end{array}$ & $\begin{array}{l}\text { Bantuan yang diberikan berbentuk } \\
\text { kapal, alat tangkap, mesin mengalami } \\
\text { bantuan kurang sesuai } \\
\text { dengan waktu musim ikan, }\end{array}$ \\
$\begin{array}{l}\text { ground dan daya jelajah mesin } \\
\text { fishing ground dan daya } \\
\text { jelajah mesin kapal }\end{array}$ & $\begin{array}{l}\text { kapal yang berubah jika musim } \\
\text { berubah }\end{array}$ & $\begin{array}{l}\text { dengan kondisi aktual yang nelayan } \\
\text { dalam melaut pada saat bantuan itu } \\
\text { dicairkan }\end{array}$ \\
\hline
\end{tabular}

Sumber: Data Primer Hasil FGD (2016)

Tabel 7. Kebijakan, masalah yang diselesaikan dan rumusan tujuan

\begin{tabular}{|c|c|c|}
\hline Kebijakan & Masalah yang Ingin Diselesaikan & Rumusan Tujuan \\
\hline $\begin{array}{l}\text { Kementerian Kelautan dan } \\
\text { Perikanan perlu merevisi } \\
\text { Petunjuk Teknis } \\
\text { (JUKNIS) Bantuan } \\
\text { langsung }\end{array}$ & $\begin{array}{l}\text { Mempermudah dan memperlancar } \\
\text { proses pencairan sehingga sesuai } \\
\text { dengan kebutuhan nelayan pada saat } \\
\text { bantuan diterima }\end{array}$ & $\begin{array}{l}\text { Menyederhanakan proses } \\
\text { penyaluran bantuan sehingga } \\
\text { implementasinya menjadi efektif } \\
\text { dan efisien }\end{array}$ \\
\hline $\begin{array}{l}\text { Petunjuk Teknis yang } \\
\text { dibuat Kementerian KKP } \\
\text { dalam pemberian } \\
\text { rekomendasi oleh Kepala } \\
\text { Dinas KKP dan Kepala } \\
\text { Desa disarankan dapat } \\
\text { diwakilkan oleh pejabat } \\
\text { setingkat dibawahnya }\end{array}$ & $\begin{array}{l}\text { Proses pengajuan bantuan dapat } \\
\text { diajukan tanpa harus menunggu tanda } \\
\text { tangan dari Kepala Dinas KKP } \\
\text { Kabupaten Sukabumi dan Kepala Desa } \\
\text { jika yang bersangkutan tidak berada di } \\
\text { tempat pada saat nelayan } \\
\text { membutuhkan rekomendasi untuk } \\
\text { pengajuan bantuan }\end{array}$ & \\
\hline
\end{tabular}

Sumber: Data Primer Hasil FGD (2016)

Kementerian Kelautan dan Perikanan perlu merevisi Petunjuk Teknis (JUKNIS) Bantuan langsung untuk kegiatan perikanan tangkap. Kedua, Petunjuk Teknis yang dibuat Kementerian KKP diusulkan agar dalam pemberian rekomendasi baik oleh Kepala Dinas KKP maupun Kepala Desa dilokasi yang menjadi sasaran bantuan dapat diwakilkan oleh pejabat setingkat dibawahnya. Dengan adanya kedua kebijakan ini akan mempermudah dan memperlancar proses pencairan dana bantuan langsung sehingga sesuai dengan kebutuhan nelayan pada saat bantuan diterima. Dari proses FGD dengan metode analisis RIA diperoleh rumusan tujuan yang hendak dicapai adalah menyederhanakan proses penyaluran bantuan sehingga implementasinya menjadi afektif dan efisien.
Dengan rumusan tujuan di atas maka akan mengakibatkan proses pengajuan bantuan dan time line-nya menjadi diketahui sehingga nelayan dapat memperoleh bantuan itu untuk dapat langsung diaplikasikan dalam proses penangkapan ikan. Dengan demikian nelayan tidak lagi menghadapi kendala ketidaksesuaian yang diakibatkan perubahan musim, fishing ground dan daya jelajah mesin kapal pada saat ikan melimpah.

Tahapan ketiga dalam pendekatan analisis kebijakan dengan pendekatan RIA adalah assesment resiko.

\section{Assesment Risiko}

Berdasarkan Tabel 9 terkait assesment risiko, lahirnya rumusan tujuan yang diuraikan dalam tebel tersebut sangat ditentukan oleh dua faktor yaitu yang bersifat penghambat dan pendorong. 
Tabel 8. Tujuan dan perilaku yang diinginkan

\begin{tabular}{ll}
\hline Tujuan yang Diinginkan & Perilaku yang Diinginkan \\
\hline Menyederhanakan proses penyaluran & Proses pengajuan bantuan dan time line-nya menjadi diketahui \\
bantuan sehingga implementasinya menjadi & sehingga nelayan dapat mendapatkan bantuan itu untuk \\
efektif dan efisien & dapat langsung diaplikasikan dalam proses penangkapan \\
& ikan. Dengan demikian nelayan tidak lagi menghadapi \\
& kendala ketidaksesuaian yang diakibatkan perubahan musim, \\
& fishing ground dan daya jelajah mesin kapal pada saat ikan \\
melimpah
\end{tabular}

Sumber: Data Primer Hasil FGD (2016)

Tabel 9. Tujuan, faktor penghambat dan pendorong, pihak yang diuntunngkan dan dirugikan

\begin{tabular}{|c|c|c|c|c|}
\hline Tujuan & Faktor Penghambat & Faktor Pendorong & $\begin{array}{c}\text { Pihak yang } \\
\text { Diuntungkan }\end{array}$ & $\begin{array}{c}\text { Pihak yang } \\
\text { Dirugikan }\end{array}$ \\
\hline \multirow[t]{2}{*}{$\begin{array}{l}\text { Menyederhanakan } \\
\text { proses penyaluran } \\
\text { bantuan sehingga } \\
\text { implementasinya } \\
\text { menjadi efektif dan } \\
\text { efisien }\end{array}$} & $\begin{array}{l}\text { Faktor Alam: } \\
\text { - Perubahan musim } \\
\text { ikan dan fishing } \\
\text { ground ikan pada saat } \\
\text { bantuan diterima } \\
\text { nelayan } \\
\text { - Musim paceklik } \\
\text { yang dialami } \\
\text { nelayan } \\
\text { menyebabkan alat } \\
\text { bantuan yang sudah } \\
\text { diterima menjadi } \\
\text { tidak beroperasi } \\
\text { karena fishing ground } \\
\text { dan musim ikan } \\
\text { berubah sehingga } \\
\text { daya jelajah kapal } \\
\text { harus menigkat dan } \\
\text { membutuhkan } \\
\text { ukuran kapal, jenis } \\
\text { alat tangkap dan } \\
\text { mesin yang } \\
\text { kapasitasnya } \\
\text { ditingkatkan }\end{array}$ & $\begin{array}{l}\text { Nelayan (terutama } \\
\text { nelayan buruh) yang } \\
\text { tergabung dalam } \\
\text { kelompok (KUB) ingin } \\
\text { secepatnya } \\
\text { mendapatkan bantuan } \\
\text { agar memiliki aset } \\
\text { berupa kapal, dan alat } \\
\text { tangkapnya sehingga } \\
\text { mereka dapat melaut }\end{array}$ & $\begin{array}{l}\text { Nelayan } \\
\text { penerima } \\
\text { bantuan }\end{array}$ & $\begin{array}{l}\text { Tidak ada } \\
\text { pihak yang } \\
\text { dirugikan }\end{array}$ \\
\hline & $\begin{array}{l}\text { Faktor teknis: mesin } \\
\text { kapal yang digunakan } \\
\text { jika terjadi perubahan } \\
\text { tersebut tidak sesuai lagi } \\
\text { dengan kondiai alamiah } \\
\text { yang terjadi sehingga } \\
\text { kapasitasnya perlu } \\
\text { ditingkatkan }\end{array}$ & $\begin{array}{l}\text { Perubahan musim dan } \\
\text { fisbing ground } \\
\text { menyebabkan nelayan } \\
\text { ingin menangkap ikan } \\
\text { lebih jauh lagi }\end{array}$ & & \\
\hline
\end{tabular}

Sumber: Data Primer Hasil FGD (2016)

Faktor penghambat yang mempengaruhi keefektifan pemberian bantuan langsung PUMP Perikanan Tangkap di Kabupaten Sukabumi adalah faktor alam dan teknis. Faktor alam terutama terkait dengan perubahan musim tangkapan ikan, fishing ground ikan dan musim paceklik. Sementara faktor teknis terkait dengan sarana produksi perikanan yang telah keluar dananya tidak sesuai lagi dengan kondisi alamiah yang dihadapi nelayan. Kondisi alamiah tersebut 
mengharuskan kapasitas sarana produksi perikanan ditingkatkan.

Faktor pendorong yang mempengaruhinya adalah keinginan nelayan untuk secepatnya memanfaatkan bantuan langsung agar mendapatkan sarana produksi perikanan tangkap yang diinginkan yang disesuaikan dengan perubahan kondisi alam maupun teknisnya. Dengan demikian, dalam implementasinya program ini nelayan yang mendapatkan keuntungan dan manfaatnya. Tahapan berikutnya dari pendekatan analisis RIA dalam mengevaluasi Program PUMP Perikanan Tangkap adalah perumusan alternatif kebijakan seperti disajikan pada Tabel 10. Dari alternatif kebijakan tersebut dilakukan screening alternatif tindakan dengan mekanisme skoring (Tabel 11).

Hasil skoring secara kuantitatif menunjukkan bahwa alternatif tindakan kebijakan-1 menjadi prioritas dan sangat penting kemudian disusul alternatif ke-2 dan ke-3 untuk memperbaiki program bantuan langsung PUMP Perikanan Tangkap di Kabupaten Sukabumi. Manfaat Biaya terkait pilihan alternatif kebijakan prioritas dalam penyaluran bantuan PUMP Perikanan Tangkap di Kabupaten Sukabumi disajikan pada Tabel 12.

Dari ketiga pilihan alternatif kebijakan prioritas diperkirakan akan diperoleh manfaat/ biaya seperti disajikan dalam Tabel 13.

Dampak dari kebijakan bantuan langsung

Tabel 10. Alternatif kebijakan

\begin{tabular}{|c|c|c|}
\hline Tujuan & Alternatif (Tindakan) dengan Cara Lain & Alternatif ke-i \\
\hline \multirow{18}{*}{$\begin{array}{l}\text { Menyederhanakan proses } \\
\text { penyaluran bantuan } \\
\text { sehingga implementasinya } \\
\text { menjadi afektif dan efisien }\end{array}$} & Kementerian Kelautan dan Perikanan Republik & \multirow[t]{5}{*}{1} \\
\hline & Indonesia merevisi Pedoman Program PUMP Perikanan & \\
\hline & Tangkap dan petunjuk teknisnya agar proses & \\
\hline & administrasi penyaluran bantuan langsung tidak bersifat & \\
\hline & $\begin{array}{l}\text { "rigid" tetapi fleksibel dan tetap mengutamakan } \\
\text { tatakelola keuangan yang akuntabel dan dapat } \\
\text { dipertanggungjawabkan }\end{array}$ & \\
\hline & Kepala Dinas Kelautan dan Perikanan Kabupaten & \multirow[t]{7}{*}{2} \\
\hline & Sukabumi memberikan kewenangan kepada pejabat & \\
\hline & instansi dibawahnya untuk mewakilkan dalam pemberian & \\
\hline & rekomendasi/pengesahan untuk pencairan bantuan & \\
\hline & langsung PUMP Perikanan Tangkap apabila Kepala & \\
\hline & Dinas tidak berada di tempat. Misalnya: Sekretaris Dinas & \\
\hline & KKP Kabupaten Sukabumi & \\
\hline & Kepala Desa yang mana KUB Nelayan berada juga & \multirow[t]{6}{*}{3} \\
\hline & dapat memberikan kewenangan untuk diwakilkan & \\
\hline & kepada pejabat setingkat dibawahnya untuk & \\
\hline & pengesahan/rekomendasi dalam pencairan bantuan & \\
\hline & langsung PUMP Perikanan Tangkap. Misalnya: & \\
\hline & Sekretaris Desa tempat lokasi KUB tersebut berada & \\
\hline
\end{tabular}

Sumber: Data Primer Hasil FGD (2016)

Tabel 11. Screening alternatif tindakan dengan mekanisme skoring

\begin{tabular}{cccccc}
\hline $\begin{array}{c}\text { Alternatif } \\
\text { Tindakan }\end{array}$ & Legalitas & Biaya & Dampak & $\begin{array}{c}\text { Kemungkinan } \\
\text { Mencapai Tujuan }\end{array}$ & Total \\
\cline { 2 - 6 } & & 0 & 2 & 4 & 6 \\
2 & 0 & 0 & 2 & 3 & 5 \\
3 & 0 & 0 & 2 & 3 & 5 \\
\hline
\end{tabular}


Tabel 12. Manfaat - biaya dari pilihan alternatif kebijakan prioritas

\begin{tabular}{|c|c|c|c|c|}
\hline Kelompok & Jenis Manfaat & Nilai Manfaat & Jenis Biaya & $\begin{array}{l}\text { Nilai } \\
\text { Biaya }\end{array}$ \\
\hline \multicolumn{5}{|c|}{ Alternatif Kebijakan Prioritas-1 } \\
\hline $\begin{array}{l}\text { Kementerian } \\
\text { Kelautan dan } \\
\text { Perikanan }\end{array}$ & $\begin{array}{l}\text { Program bantuan KKP } \\
\text { berjalan efektif dan efisien } \\
\text { Program bantuan memiliki } \\
\text { akuntabilitas dan dapat } \\
\text { dipertanggungjawabkan } \\
\text { sehingga penyalurannya tepat } \\
\text { sasaran }\end{array}$ & Tinggi & Tidak ada biaya & - \\
\hline \multicolumn{5}{|c|}{ Alternatif Kebijakan Prioritas-2 } \\
\hline $\begin{array}{l}\text { Dinas Perikanan } \\
\text { dan Kelautan } \\
\text { Kabupaten } \\
\text { Sukabumi }\end{array}$ & $\begin{array}{l}\text { Dinas KKP Kabupaten } \\
\text { Sukabumi dapat } \\
\text { memberdayakan Nelayan } \\
\text { dalam KUB Fajar Mandiri }\end{array}$ & Tinggi & Tidak ada biaya & - \\
\hline \multicolumn{5}{|c|}{ Alternatif Kebijakan Prioritas-3 } \\
\hline $\begin{array}{l}\text { Pemerintah Desa } \\
\text { Cikahuripan } \\
\text { Kecamatan Cisolok } \\
\text { Kabupaten } \\
\text { Sukabum }\end{array}$ & $\begin{array}{l}\text { Memberdayakan masyarakat } \\
\text { Desa Cikahuripan Kecamatan } \\
\text { Cisolok Kabupaten Sukabum } \\
\text { khususnya yang berprofesi } \\
\text { sebagai nelayan dan buruh } \\
\text { nelayan }\end{array}$ & Tinggi & Tidak ada biaya & - \\
\hline KUB Fajar Mandiri & $\begin{array}{l}\text { Nelayan yang sudah memiliki } \\
\text { aset seperti kapal, alat tangkap } \\
\text { bisa menambah kapasitas aset } \\
\text { dalam faktor produksi seperti } \\
\text { mesin, alat tangkap dan kapal } \\
\text { Bagi buruh nelayan yang } \\
\text { belum memiliki faktor } \\
\text { produksi (kapal, dan alat } \\
\text { tangkapnya) mendapatkan } \\
\text { aset berupa kapal dan alat } \\
\text { tangkap }\end{array}$ & Tinggi & Biayanya kecil & - \\
\hline
\end{tabular}

PUMP Perikanan Tangkap Tahun 2011 dapat digunakan indikator yang telah dirumuskan dalam Keputusan Direktur Jenderal Perikanan Tangkap No 32 Tahun 2014 tentang Pedoman Teknis Pelaksanaan Kegiatan Pengembangan Usaha Mina Pedesaan bidang Perikanan Tangkap tahun 2014 yang terdiri dari indikator keluaran (output) dan hasil (outcome). Indikator keluaran terdiri dari:

1. Tersalurkannya dana bantuan langsung masyarakat (BLM) PUMP Perikanan Tangkap kepada KUB sebagai modal usaha produktif penangkapan ikan
2. Termanfaatkannya BLM PUMP Perikanan Tangkap untuk kegiatan usaha produktif

3. Terlaksananya fasilitasi penguatan kapasitas dan kelembagaan KUB melalui pendampingan dan pembinaan

Sementara indikator hasil yaitu:

1. Meningkatnya pendapatan nelayan anggota KUB

2. Berkembangnya kelembagaan KUB

3. Berkembangnya kewirausahaan nelayan.

Merujuk indikator keberhasilan luaran berdasarkan hasil FGD yang diperoleh di Kabupaten Sukabumi terlihat bahwa dana 
Tabel 13. Perkiraan dampak yang akan terjadi

\begin{tabular}{|c|c|}
\hline Jenis Manfaat/Biaya & Baseline \\
\hline $\begin{array}{l}\text { Nelayan yang sudah memiliki aset seperti kapal, } \\
\text { alat tangkap bisa menambah kapasitas aset dalam } \\
\text { faktor produksi seperti mesin, alat tangkap dan } \\
\text { kapal } \\
\text { Buruh nelayan yang belum memiliki faktor } \\
\text { produksi (kapal, dan alat tangkapnya) } \\
\text { mendapatkan aset berupa kapal dan alat tangkap }\end{array}$ & $\begin{array}{l}\text { - Pada saat menerima bantuan PUMP: KUB Fajar } \\
\text { Mandiri berjumlah } 10 \text { orang yang terdiri dari } \\
\text { nelayan dan buruh nelayan } \\
\text { - Kepemilikan aset di awal menerima bantuan : } \\
\text { ada nelayan yang memiliki kapal saja tanpa } \\
\text { mesin, kapal dengan mesin tanpa alat tangkap, } \\
\text { dan sama sekali tidak memiliki faktor produksi } \\
\text { (kapal dan alat tangkap) } \\
\text { - Aset kapal yang dimiliki pada tahun } 2011 \\
\text { berjumlah } 3 \text { unit } \\
\text { - Pada tahun } 2016 \text {, secara kelembagaan KUB } \\
\text { Fajar Mandiri telah berubah menjadi Koperasi } \\
\text { Fajar Mandiri } \\
\text { - Dana bantuan PUMP yang berjumlah Rp } 100 \\
\text { juta pada saat penelitian semuanya dalam } \\
\text { bentuk aset milik nelayan yang semuanya } \\
\text { sebagai anggota koperasi sebanyak } 45 \text { orang. } \\
\text { - Dalam kurun waktu } 2011-2016 \text { aset berupa } \\
\text { kapal dengan mesin dan alat tangkap dengan } \\
\text { ukuran <5 GT berjumlah } 25 \text { unit. Artinya ada } \\
\text { pertambahan jumlah kapal dan alat tangkap dari } \\
\text { adanya bantuan kapal tahun } 2011 \\
\text { - Nelayan yang belum mendapatkan kapal dan } \\
\text { alat tangkap dalam Koperasi Fajar Mandiri } \\
\text { tinggal } 20 \text { anggota pada saat dilakukan } \\
\text { penelitian }\end{array}$ \\
\hline
\end{tabular}

Sumber: Data Primer Hasil FGD (2016)

bantuan langsung masyarakat untuk PUMP Perikanan Tangkap tahun 2011 tersalurkan kepada KUB Fajar Mandiri sebesar Rp 100 juta dan dimanfaatkan untuk membeli kapal ikan dan alat tangkapnya serta memperkuat kapasitas dan kelembagaan KUB tersebut. Penguatan kapasitas kelembagaan tersebut dilakukan oleh Dinas Kelautan dan Perikanan Kabupaten Sukabumi dan instansi lainnya melalui bimbingan teknis, pelatihan dan pendampingan.

Berdasarkan indikator keberhasilan hasil dari FGD diperoleh bahwa nelayan mengalami penambahan aset sarana produksi perikanan yang berdampak pada peningkatan kesejahteraannya. Hal ini dapat dilihat secara makro dari nilai NTN Jawa Barat tahun 2010-2013 dan perkembangan keuangan KUB Fajar Mandiri yang kemudian kelembagaannya berkembang menjadi Koperasi Fajar Mandiri. Perkembangan kewirausahaan di tingkat nelayan dapat dilihat dari perkembangan aktivitas dan keragaman usaha Koperasi Fajar Mandiri yang sebelumnya adalah KUB Fajar Mandiri. Berdasarkan kedua indikator tersebut menunjukkan bahwa nelayan dan buruh nelayan mendapatkan BLM dari program PUMP Perikanan Tangkap Tahun 2011 di Kabupaten Sukabumi mendaptkan dan menambah aset berupa faktor produksi perikanan tangkap sehingga mampu meningkatkan hasil tangkapannya dan berakibat terhadap perbaikan tingkat kesejahteraannya.

Hasil penelitian tidak berbeda jauh dengan penelitian Malinda (2016) yang menganalisis implementasi Program PUMP bidang Perikanan 
Tangkap di Kabupaten Bengkayang Tahun 2013. Nelayan di daerah ini dapat menambah sarana produksi perikanannya dengan cara mengganti alat tangkap dan memperbaiki kapal mereka yang sudah rusak sehingga mampu melaut kembali. Namun, penelitian Malinda ini juga menemukan bahwa meskipun nelayan di daerah ini telah mendapatkan bantuan BLM Program Perikanan Tangkap namun pendapatannya masih berfluktuatif akibat hambatan cuaca dalam pengoperasian kapal dan alat tangkapnya.

Penelitian lain yang dilakukan oleh Maengkom $e t$ al., (2015) menyimpulkan bahwa program PUMP di Kelurahan Tidore Kecamatan Tahuna Timur, secara prosedural telah sesuai dengan prosedur dan kriteria yang ditetapkan pemerintah. Kekurangan yang ditemukan dalam implementasinya: (i) bantuan program yang berbentuk non fisik tidak dipergunakan dengan optimal; (ii) tidak terjadi perputaran modal, dan (iii) tidak berfungsinya tenaga pembimbing, pendampingan dan pelatihan tidak berkelanjutan pasca penyaluran dana. Keluaran yang dihasilkan di daerah Kelurahan Tidore yaitu tidak berfungsinya dengan baik infrastruktur penangkapan ikan dan KUB sehingga program BLM-PUMP di daerah tersebut kurang efektif. Akibatnya tujuan program yang diinginkan tidak tercapai sepenuhnya. Sementara, dampak terhadap perekonomian nelayan yaitu terjadinya peningkatan pendapatan dan mengurangi ketergantungan terhadap pemilik modal. (individu/lembaga).

\section{Strategi Implementasi}

Program bantuan langsung PUMP Perikanan Tangkap (bantuan sosial) yang digulirkan Kementerian Kelautan dan Perikanan RI agar berjalan efektif dan efisien, maka strategi implementasinya adalah: pertama, proses penyaluran bantuan langsung PUMP Perikanan Tangkap di Kabupaten Sukabumi mestinya dilakukan melalui mekanisme penyaluran yang bersifat lebih sederhana sehingga tidak kaku serta tidak melanggar ketentuan administrasi dan birokrasi pemerintahan yang berlaku menurut peraturan perundangan.

Kedua, kondisi empiris dalam pembelian faktor produksi untuk penangkapan ikan (kapal, alat tangkap dan mesin) ditemukan bahwa anggaran yang diajukan oleh KUB nelayan berbentuk Rencana Anggaran Biaya (RAB) ketika dicairkan harga sarana produksi perikanan yang dibeli mengalami peningkatan. Akibatnya, nelayan dalam KUB Fajar Mandiri mensiasatinya dengan cara melakukan kesepakatan penanggulangan biaya kekurangannya dilakukan secara "tanggung renteng" sehingga dapat membeli kebutuhan sarana produksi penangkapan ikan sesuai harga pasaran. Jika hal ini tidak dilakukan, maka dana bantuan yang diperoleh akan melebihi jumlah yang diajukan dalam RAB sehingga berpotensi menjadi temuan. Hal ini dapat menimbulkan konsekuensi hukum meskipun hal ini hanya merupakan proses diskresi kebijakan yang disebabkan perubahan harga pembelian di pasar.

Ketiga, untuk mengatasi problem time-line dalam pencairan dana yang mengakibatkan tidak sinkronnya antara kondisi alamiah yang dialami nelayan seperti musim ikan, perubahan fishing groud dan masa paceklik, maka mekanisme pencairan dana dibuat lebih fleksibel dan prosesnya satu tahap saja dengan prasyarat tidak bertentangan dengan peraturan perundangan yang berlaku sehingga mencapai sasaran dan tujuan yang diinginkan secara optimal. Jika hal ini tidak dilakukan, maka akan menimbulkan dilematis karena di satu sisi KKP harus bekerja dalam 
kerangka proses penganggaran menurut UndangUndang Anggaran Pendapatan dan Belanja Negara dalam tahun yang berlaku. Namun di sisi lain, nelayan harus memanfaatkan dana bantuan langsung tersebut untuk membeli kapal dan alat tangkap yang sesuai dengan musim ikan yang sedang melimpah pada tahun yang sedang berjalan. Dampak dari dilematis ini dana bantuan langsung yang dicairkan kurang tepat waktu dan tidak sinkron dengan kondisi aktual nelayan. Ditambah lagi proses pencairannya berlangsung selama dua tahap sehingga menyebabkan pembelian kapal, mesin dan alat tangkap sedikit tersendat.

\section{REFERENSI}

[BPS] Badan Pusat Statsitik. 2015. Statistik Nilai Tukar Petani di Jawa Barat 2014. BPS Jawa Barat 2015.

[BPS] Badan Pusat Statsitik. 2016. Statistik Nilai Tukar Petani di Jawa Barat 2015. BPS Jawa Barat 2016.

[Bappenas] Badan Perencanaan Pembangunan Nasional. 2011. Pengembangan dan Implementasi Metode Regulatory Impact Analysis (RIA) untuk Menilai Kebijakan (Peraturan dan Non-Peraturan) di Kementerian PPN/Bappenas. Diterbitkan oleh Biro Hukum Kementerian Perencanaan Pembangunan Nasional/ BAPPENAS.

[Ditjend Tangkap-KKP] Direktorat Jenderal Perikanan Tangkap Kementerian Kelautan dan Perikanan. 2014. Pedoman Teknis Pelaksanaan Kegiatan Pengembangan Usaha Mina Pedesaan bidang Perikanan Tangkap. Jakarta. Dirjend Perikanan Tangkap.
Hikmayani, Y., Maharani, Yulisti. 2015. Dampak Ekonomi Program Pengembangan Usaha Mina Pedesaan (PUMP) pada Usaha Pengolahan dan Pemasaran Hasil Perikanan. Sosial Ekonomi, Kelautan dan Perikanan 10 (2) 2015. pp: 229-240.

Irwanto. 2006. Focus Group Discussion /OBR. Penerbit Yayasan Obor Indonesia

Kirkpatrick, C., Yin-Fang, Z. 2004. Regulatory Impact Assessment in Developing and Transition Economies: A Survey of Current Practice. Institute for Development Policy and Management. University of Manchester.

[KKP] Kementerian Kelautan dan Perikanan. 2011a. Peraturan Menteri Kelautan dan Perikanan No 41 Tahun 2011 tentang Pedoman Pelaksanaan Program Nasional Pemberdayaan Masyarakat Mandiri Kelautan dan Perikanan.

[KKP $]$ Kementerian Kelautan dan Perikanan. 2011b. PNPM Mandiri Menyentuh Nelayan.

23 April 2016. Diakses pada http://www. kkp. go.id.

[KKP] Kementerian Kelautan dan Perikanan.

2013. Peraturan Menteri Kelautan dan Perikanan No 2 Tahun 2013 tentang Pedoman Pelaksanaan Program Nasional Pemberdayaan Masyarakat Mandiri Kelautan dan Perikanan.

[KKP] Kementerian Kelautan dan Perikanan. 2014. Peraturan Menteri Kelautan dan Perikanan No. 10 Tahun 2014 tentang Pedoman Pelaksanaan Program Nasional Pemberdayaan Masyarakat Mandiri Kelautan dan Perikanan.

Kusnadi. 2003. Akar Kemiskinan Nelayan. Yogyakarta: Penerbit Lkis. 
Malinda, U.G. 2016. Impelementasi Program Pengembangan Usaha Mina Perdesaan Bidang Perikanan Tangkap di Wilayah Pesisir Kabupaten Bengkayang Tahun 2013. Governance. 2 (2) 2016. pp: 1-13.

Maengkom, V., Leonardus, R. Rengkung., Agnes L. Loho. 2015. Evaluasi Pengembangan Ekonomi Nelayan Peneriman Program Bantuan Langsung Masyarakat Pengembangan Usaha Mina Perdesaan (BLM-PUMP) di Kelurahan Tidore. ASE 11 (2A) 2015. pp: 77 - 88.

Nasokah. 2008. Implementasi Regulatory Impact Assessment (RIA) Sebagai Upaya Menjamin Partisipasi Masyarakat Dalam Penyusunan Peraturan Daerah. Jurnal Hukum. Vol 15(3) Juli 2008. Hal. 443-458.

[OECD] Organisation for Economic Cooperation and Development. 2008.
Introductory Handbook for Undertaking Regulatory Impact Analysis (RIA). Version 1 October 2008. Published by Organisation for Economic Co-operation and Development.

Sunardi., Erlan. 2016. Kisah Sukses KUB Fajar Mandiri. Laporan Penyuluh Perikanan Bantu Bidang Perikanan Tangkap. Dinas Perikanan dan Kelautan Kabupaten Sukabumi. Jawa Barat.

Wardani, R.S., Dwi, Winarto, J., Rudyanto, Ing, Bambang., Hernadi., Harefa, M., Tanjung, A., Nurhayati, S., Rongiyati, S., Hariyadi., Kurnianingsih, T. 2008. Panduan Penerapan Metode Analisis Dampak Regulasi (Regulatory Impact Assessment/RIA) di Lingkungan DPR-RI. Penerbit Sekretariat Jenderal DPR RI. 